\title{
Using GIS to study the probability pollution of surface soil in Babylon province, Iraq.
}

\author{
Jwad K. Manii \\ (BabylonUniversity-Department of Applied geology)
}

\begin{abstract}
This study presents results on the environment characteristics of Babylon provincea geochemical survey was carried out. The survey provided data on the three trace element contents, $\mathrm{Cr}, \mathrm{Ni}$ and $\mathrm{Pb}$ levels in soil samples determined using AAS. The trace element concentrations contents in soils agreed normal range values of natural soils. These results showed that there had been pollution of $\mathrm{Ni}$ in the some sampling points where the maximum values obtained more than the maximum allowable values. Spatial distributions of, $\mathrm{Cr}, \mathrm{Ni}$, and $\mathrm{Pb}$ were plotted in relation to the concentration values in soil using Geographic Information System (GIS) technology.
\end{abstract}

\section{Introduction}

Soils are porous media created at the land surface through weathering processes mediated by biological, geological, and hydrological phenomena. Soils differ from mere weathered rock, however, because they show an approximately vertical stratification (the soil horizons) that has been produced by the continual influence of percolating water and living organisms(G.Sposito,2008). Soil contamination by trace elements is a significant issue on a global scale, mainly due to industrial and mining activities. Moreover, can produce great disasters that may have serious impacts on the environment for decades(Romero et al.,2012) Industrial activities releasing metals or organic particulates impact surrounding soils. These pollutants pose a significant risk for health and the natural environment(M.D.Somoano et al.,2012). Increasing concentrations of heavy metals in the environment result in continuously growing importance for elemental analysis in environmental samples (Florian et al.,199\&Falciani et al.,2010). Elevated metal loads in soil result in increased uptake by plants and thereby accumulate in the food chain. Thus any soil amendment and fertilizer such as compost, which are used as fertilizer, should be monitored for their elemental concentrations. Though total concentrations of metals in soil is used to characterize its base-line elemental composition (parent geological material), total metal concentration analysis allows to assess soil pollution and to ascertain heavy metal and other pollutant contents in the soil. Although different procedures have been described to determine total metal contents, the most widely adopted method is digestion (S.Oztan\& R.-A.During,2012). The aim of this study was to contribute to the knowledge of the state of the province environment . Our study focused on the determination of concentrations of trace elements in soil samples, then use GIS in mapping the concentration distribution. The work is intended to be a base for future investigations of activities leading to temporary changes in concentrations of elements in this region soil. Distribution maps produced will help to clarify the situation in the region with respect to heavy metallevel.

\section{Material and Methods:}

\section{Study area}

Babylon province location inside Iraq Coordinates: is situated between longitudes $44^{\circ} 00^{\prime}-45^{\circ} 00^{\prime} \mathrm{E}$ and latitudes $32^{\circ} 00^{\prime}-33^{\circ} 15^{\prime} \mathrm{N}$. Hilla city.is a central. It is the capital of Babylon province and is located near the ancient cities of Babylon one the Hilla branch of the Euphrates River, $100 \mathrm{~km}$ south of Baghdad It is situated in a predominantly agricultural region which is extensively irrigated with water provided by the Hilla river. This region is one of the most important agricultural areas of Iraq and has very fertile soils. Theorganic matter content of the topsoil is normally low. The climate is semi-arid with a mean annual rainfall ranging from less than $50 \mathrm{~mm}$ to about $200 \mathrm{~mm}$.The temperature in summer can reach as high as $50^{\circ} \mathrm{C}$ during day time. Dominate warm winter(National Meteorology Institute). Geologically, the study area is characterized by Holocene sediments are mainly constituted by clay,silt and sand as typical sediments of flood plane systems. Fig. 1 shows this region.

\section{Sampling and chemical analysis:}

Soil samples used in this study were collected from locations within study areas shown in (Fig. 1). The sampling points in each area were selected on the flat terrain and far from major roads. Soil samples from the 26 soil sitewith $(0-20 \mathrm{~cm}$ deep) were collected for investigating the distribution of Soil trace elements in upper soil horizons. Samples were collected using plastic tools and stored in plastic bags. All sampling sites were 
recorded by global positioning system (GPS) and the related information such as land-use history, vegetation, soil type, and present and potential pollutant sources were also recorded in detail.The collected soil samples were air dried and then ground to 100 meshes for chemical analysis. The soil samples were digested by reverse aqua regia $(\mathrm{HCl} / \mathrm{HNO} 3=1 / 3)$ (Burt et al. 2003). and the total concentrations of $\mathrm{Cr}, \mathrm{Ni}$, and $\mathrm{Pb}$ were determined by flame atomic absorption spectrometry (AAS 6300, Shimadzu, Japan). The $\mathrm{pH}$ was determined in triplicate in $10 \mathrm{~g}$ of soil mixed with $25 \mathrm{ml}$ of distilled water after $10 \mathrm{~min}$ of shaking and $30 \mathrm{~min}$ of rest, using a(Microph 2002) $\mathrm{pH}$-meter calibrated with buffer solutions at $\mathrm{pH}=4$ and $\mathrm{pH}=7$. Bulk mineralogical analysis was performed by X-ray diffraction (XRD) powder method at Babylon university fore sum soil samples . The sample was loaded on a side-loading sample holder and scanned using a (PW117/01 sample stage holder modal Xpert PRO MPD PaNalytical) with monochromatic $\mathrm{Cu} \mathrm{K \alpha}$ radiation at $30 \mathrm{~mA}$ and $40 \mathrm{kV}$. Samples were scanned at standard conditions between $5^{\circ}$ and $70^{\circ} 2 \theta$ at a speed of $2^{\circ} 2 \theta /$ min The powder $\mathrm{X}$-ray diffraction patterns and A full summary of the mineralogical results are presented in figure(2).

\section{Heavy metals and trace elements.}

This title is used to cover a number of metals (and their ions) which are mostly of high density and belong largely to the group 'transition elements' of the periodic table. Some of these have also been termed trace elements or micronutrients in agriculture, stressing their relatively low abundance inregular soil and the fact that they tend to be essential for plant growth. Other trace elements of non-metallic nature but presumably sometimes involved in pollution problems ( G.H. Bolt\& M.G.M. Bruggnwertm,1978).In anther word trace elements refer to a number of elements that occur in naturalsystems in small concentrations. Trace elements includechemical elements used by organisms in small quantities that are essential totheir physiology as well as those elements with no known physiologicalfunction, which are toxic to living organisms at high concentrations(Bradford et al., 1996).

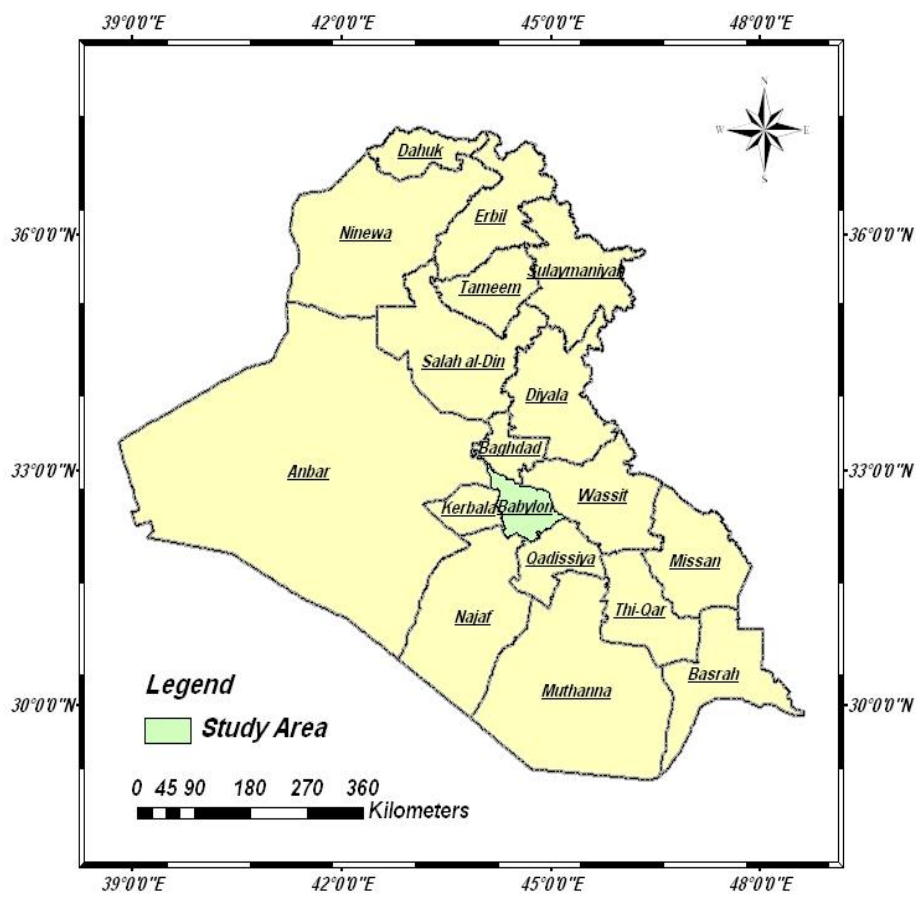

Fig. 1: Location map of the study area

\section{Geochemical mappıng:}

The GIS (Geographic Information System) mapping technique was employed to studied the spatial distribution maps for three polluting elements in soils of Babylon Province with Geostatistical analyst, you can easily create a continuous surface, or map, from measured sample points stored in a point-feature. The sample points measurements the levels of pollution, The usefulness of this technique in environmental studies has alreadybeen demonstrated by (Albanese et al. ,2008); .Kriging is used to estimate the value of a soil property at a location where the value is unknown by using the known values at locations about the point of interest. 


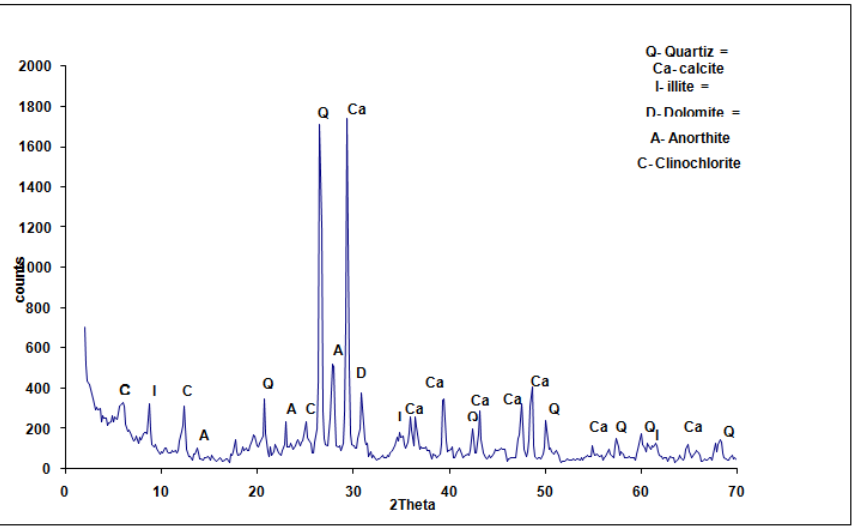

Figure (2) Representative XRD Chart for Special Diffraction Pattern of the Minerals in soil

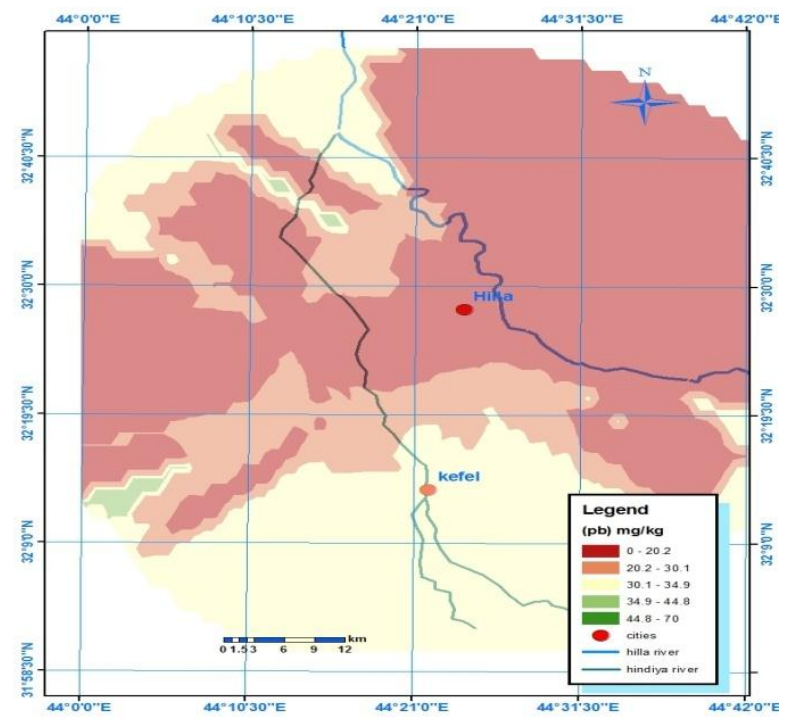

Figure 3.Pb trace element concentrations spatial distribution map

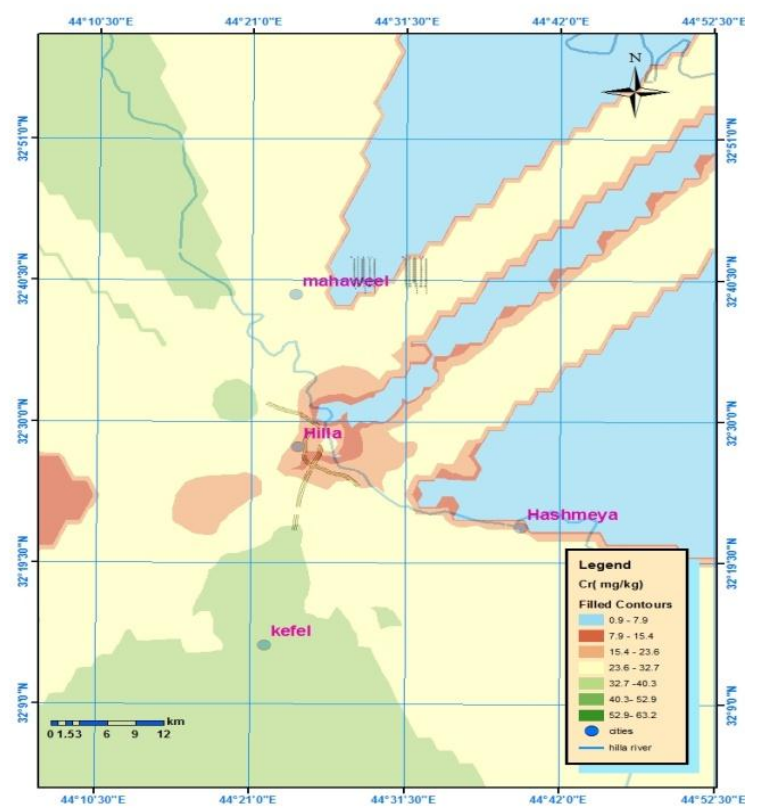

Figure 4. Cr trace element concentrations spatial distribution map 


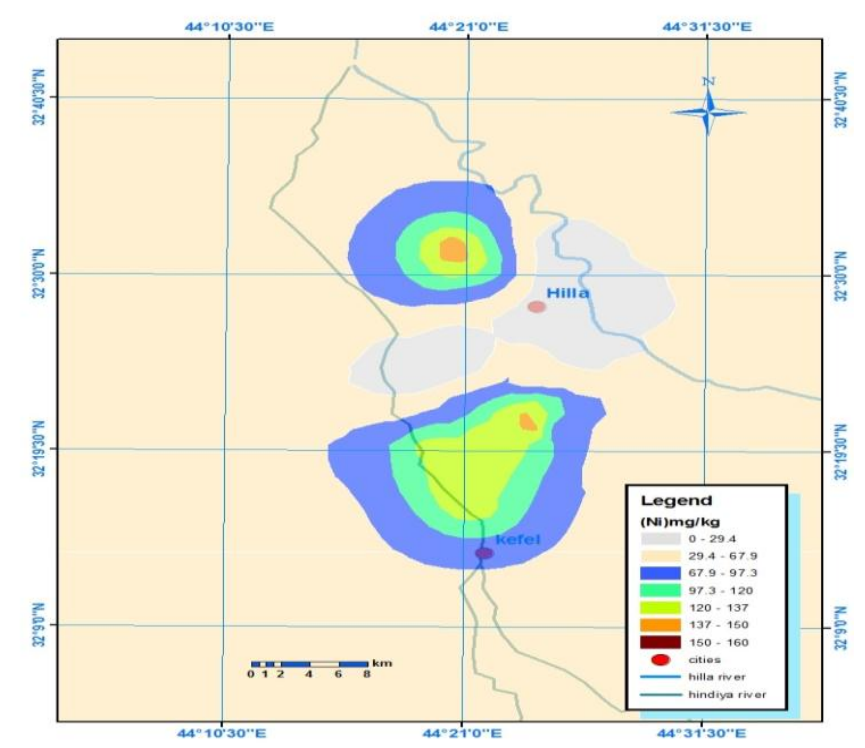

Figure 5. Ni trace element concentrations spatial distribution map

TABLE IDescriptive statistics for heavy metals studied in this work $(\mathrm{mg} / \mathrm{kg})$ and Normal range of heavy metals

\begin{tabular}{|l|l|l|l|l|l|l|l|}
\hline Metals & $\begin{array}{l}\text { Maximum } \\
\text { allowable } \\
\text { level) }\end{array}$ & $\begin{array}{l}\text { Range in } \\
\text { natural soil }\end{array}$ & $\begin{array}{l}\text { World } \\
\text { median }^{\mathrm{a}}\end{array}$ & $\begin{array}{l}\text { Present study } \\
\text { (range) }\end{array}$ & $\begin{array}{l}\text { Present study } \\
\text { (Median) }\end{array}$ & $\begin{array}{l}\text { Heavy Metal in } \\
\text { Soil within } \\
\text { Baghdad City, } \\
\text { Iraq(median) }\end{array}$ & $\begin{array}{l}\text { Heavy Metal in } \\
\text { Soil within } \\
\text { Damascus City, } \\
\text { syria (median) }\end{array}$ \\
\hline $\mathrm{Cr}$ & 250 & $7-4.28$ & 50 & $0.9-63.2$ & 34.6 & 31.65 & 78.67 \\
\hline $\mathrm{Ni}$ & 100 & $1-1000$ & 70 & $0.35-160$ & 119 & 71 & 35 \\
\hline $\mathrm{Pb}$ & 150 & $2-200$ & 35 & $0.1-70$ & 31.5 & 79.82 & 10 \\
\hline $\mathrm{Ph}$ & & & & $7.2-7.6$ & 7.4 & & \\
\hline
\end{tabular}
(a) Bowen (1979)
(b) Lacatusu, R.: 1998; EEA, 1999.
(c) A.M.J Al obaidy et al ,2013.

\section{Results and discussion:}

The results of analysis of Babylon Province soils trace elements values are presented intable (1). We measured $\mathrm{Cr}, \mathrm{Ni}$ and $\mathrm{Pb}$ elements. Chromiumconcentration values have ranged from 0.9 to $63.2(\mathrm{mg} / \mathrm{kg})$ with an median value of $34.6(\mathrm{mg} / \mathrm{kg})$. Nickel concentrationshave been found in the range of $0.3-160 \mathrm{mg} / \mathrm{kg}$ with median value of $119 \mathrm{mg} / \mathrm{kg}$. Lead concentrationsare in the range of $0.1-70 \mathrm{mg} / \mathrm{kg}$ and themedian value is 31.5 $\mathrm{mg} / \mathrm{kg}$. Present results for $\mathrm{Cr}, \mathrm{Ni}$, and , $\mathrm{Pb}$ were compared with internationalreference values for soils (EEA, 1999; Lacatusu,1998, were listed in Table 1.The present maximum values of all elements in Table 1 except $\mathrm{Cr}$ are below than the maximum value of normal range values of natural soils cited bythe EEA report. On theother hand, the maximum values of $\mathrm{Cr}, \mathrm{Ni}$ and $\mathrm{Pb}$ arebelow thanthe maximum allowable levels of standard values.These results showed that there had been pollution of $\mathrm{Ni}$ in thesome sampling points where the maximum values obtained more than the maximum allowable values. The results obtained in this work are also comparedwith theworld median values for soil .The present median values also show close agreement inmost cases with world median values for soil (Bowen, 1979). The above results show that there are some areas region that are polluted with heavy metal $(\mathrm{Ni})$ to undesirable levels. A comparison of metal concentration in study area soil and Baghdad City Damascus City The investigation of soil heavy metal content indicated that the concentrations of Ni often exceeded the calculated median for the Baghdad and Damascus City soil, while soil in study area displays lower values of pb than in Baghdad soil. It can also observe that study area soil exceeded values of $\mathrm{Pb}$ than the reported values of soil in Damascus City. Spatial distributions of elements were plotted according to their concentrations (Figures 3,4,5).

\section{References}

[1] Abdul Hameed M. J. Al Obaidy, Athmar A. M. Al Mashhadi (2013) Heavy Metal contaminations in Urban Soil within Baghdad City, Iraq Journal of Environmental Protection, 4, 72-82.

[2] Romero , I. González, I.M. Fernández, E. Galán (2012). Evaluation of trace element contamination changes in soils using a new normalization factor Application to the Guadiamar soils (SW Spain) affected by a mine spill in 1998, Journal of Geochemical Exploration .GEXPLO-05045; No of Pages 11. 
[3] Bowen, H. J. M.(1979). The Environmental Chemistry of the Elements, Academic Press, London, New York.

[4] Bradford G.R., Chang A.C., Page A.L., Bakhtar D. Frampton JA, Wright H. Background(1996)

[5] Concentrations of Trace and Major Elements in California Soils. Kearney Foundation of Soil Science Special Report. University of California.

[6] Burt R, Wilson MA, Mays MD, Lee CW (2003). Major and trace elements of selected pedons in the USA. J Environ Qual 32:21092121Burt R, Wilson MA, Mays MD, Lee CW (2003) Major and trace elements of selected pedons in the USA. J Environ Qual 32:2109-2121

[7] EEA(Environment in the European Union at the turn of the century).(1999). 'Environmental assessment No.2, Prepared in collaboration with a large number of individuals in EEA, EIONET and other institutions', Published by the European Environment Agency, Copenhagen, 446 pp, ISBN: 92-9167-202-0, Catalogue No: GH-18-98-784-EN-C.

[8] Garrison Sposito. ( 2008) The chemistry of soils / Copyright $\odot 2008$ by Oxford University Press, Inc.

[9] G.H. Bolt and M.G.M. Bruggenwert (1987) soil chemistry a basic elements Elsevier scientific publishing company.

[10] lbanese, S., Cicchella, D., Lima, A., De Vivo, B. (2008). Urban geochemical mapping. In: De

[11] Vivo, B., Belkin, H.E., Lima, A. (Eds.), Environmental Geochemistry: Site Characterization,

[12] Data Analysis and Case Histories. Elsevier, Amsterdam, pp. 359-389.

[13] Lacatusu, R.(1998).'Appraising level of soil contamination and pollution with heavy metals. In: Land Information Systems: Developments for planning the sustainable use of land resources', H. J.Heineke,W. Eckelmann, A. J. Thomasson, R. J. A. Jones, L. Montanarella and B. Buckley (eds.).European Soil Bureau Research Report No.4, EUR 17729 EN, 393-402.

[14] Page A.L.(1978). Fate and effects of trace elements in sewage sludge when applied to agriculturallands. US Environmental Protection Agency Report No. EPA670/2-74-005.

[15] Mercedes Díaz-Somoano, M. Antonia López-Antón, Isabel Suárez-Ruiz, Montserrat Calvo, Sonia Suárez,RobertoGarcía, M. Rosa Martínez-Tarazona.(2012). Impact of a semi-industrial coke processing plant in the surrounding surface soil Part I: Trace element content . Fuel Processing Technology 102 (2012) 35-45

[16] SezinO"ztan n, Rolf-Alexander During(2012). Microwave assisted EDTA extraction determination of pseudo total contents of distinct trace elements in solid environmental matrices. Talanta 99 (2012) 594-602. 